\title{
Retoriğin Temel Unsurları Olan Ethos-Pathos-Logos Perspektifinden İkna Sanatının Kullanılışı: Müge Anlı Örneği
}

\section{Elif Hatice BAHÇECİOĞLU ${ }^{1}$}

\section{Özet}

Antik çağlardan günümüze kadar gelen ve etkili konuşmanın özünü oluşturan retorik, ikna sanatının da temelidir. Hem akademik bir disiplin hem de metodolojik bir yöntem olarak gelişen retoriğin ikna sanatını kanıtlamaya yönelik ethos, pathos ve logos olmak üzere üç temel unsuru bulunmaktadır. $\mathrm{Bu}$ üç unsurun ele alınan konu çerçevesinde, konuşmacının meziyetleri doğrultusunda işlenerek etkin bir şekilde kullanılması oldukça önemlidir. Çünkü bu meziyetler aracılığıyla sunulan görüş çerçevesinde dinleyicinin etkilenerek ikna olduğu varsayılmaktadır. Bu yaklaşımlar doğrultusunda özellikle medyada yer alan kişilerin uzun dönem ekranda kalmayı başarabilmesi, retoriği kullanma konusunda ne derece etkin olduğu sorusunu akıllara getirmektedir. Buradan yola çıkarak çalışmanın amacı, belli bir olay doğrultusunda Müge Anlı'nın kullandığı argümanlara yönelmek ve bu argümanlarda retoriksel unsurların olup olmadığını irdeleyerek, varsa nasıl kullandığını ortaya koymaktır. Müge Anlı'nın çalışma kapsamında retorik kullanımlarına yönelik tespit edilen özellikleri; güven vermek, empati kurmak, ikna ederek geçmişte kalmış olayların taraflarını ekrana çekmeyi başarmak ve onları konuşturarak olayları çözüme kavuşturmaktadır. $\mathrm{Bu}$ amaçla Anlı'nın konuşmaları deşifre edilmiş ve somut ifadeler üzerinden çıkarımda bulunmaya çalışılmıştır. Çalışmanın kapsamı, durum çalışması doğrultusunda tek bir program ile sınırlandırılmış ve retorik analiz yöntemi kullanılmıştır. $\mathrm{Bu}$ anlamda ethos, pathos, logos unsurlarının nasıl kullanıldığı tespit edilmiştir. Analiz sonucunda Müge Anlı'nın güçlü bir retorik sunucusu olduğu kanısına varılmıştır. $\mathrm{Bu}$ çalışmanın hem benzer program yapanların Anlı'nın retoriği nasıl kullandığını daha kolay anlayabilmesine ve kendi programlarında yararlanmalarına hem de Müge Anlı'nın kullandığı retorik unsurları tablolaştırarak benzer çalışma yapanlar için yol gösterici olmasına katkı sunması umulmaktadır.

\footnotetext{
1 Doktora Öğrencisi, Marmara Üniversitesi, Sosyal Bilimler Enstitüsü, Radyo, Televizyon ve Sinema Anabilimdalı elifbahcecioglu@gmail.com Orcid ID: 0000-0002-6747-9250

Bu makaleye atıf için: Bahçecioğlu, E. H. (2021). Retoriğin Temel Unsurları Olan Ethos-Pathos-Logos Perspektifinden İkna Sanatının Kullanılışı Müge Anlı Örneği. Aksaray İletişim Dergisi, 3(1), 16-42. doi:10.47771/aid.783923
} 
Anahtar kelimeler: retorik, ikna sanat, medya

\title{
The Use of Persuasion from the Perspective of Ethos-Pathos-Logos which is the Basic Elements of Rhetoric: The Example of Müge Anlı
}

\begin{abstract}
Rhetoric, which has come from ancient times to today and is the essence of effective speech, is also the basis of persuasion art. The rhetoric, which has developed both as an academic discipline and as a methodological method, has three main elements, namely ethos, pathos and logos, to prove the art of persuasion. Within the framework of the subject discussed, it is very important to use these three elements in an effective way by processing them according to the merits of the speaker. Because the audience is assumed to be convinced by being influenced within the framework of the view provided through these merits. In line with these approaches, especially people in the media are able to stay on the screen for a long time raises the question of how effective it is in using rhetoric. Bases on this, the aim of study is to turn to the arguments of Anll uses in the direction of a certain event and to examine whether there are rhetorical elements in these arguments and to reveal how she used it. The characteristic of Müge Anlı which were determined for her rhetoric usage within the scope of the study; to give confidence, to empathize, to persuade the people of the past events to screen and resolve the events by making them talk. The scope of the study was limited to a single program in line with the case study. In addition, rhetorical analysis method was used and in this sense, how the elements of ethos, pathos, logos were applied was determined. As a result of the analysis, it was concluded that Müge Anlı was a powerful rhetorical presenter. It is hoped that this study both help to similar program makers that Anl1 how use rhetorical elements to understand more easily and make use of it in their own programs and to be guide for those who do similar studies by tabulating the rhetorical elements that Müge Anlı uses.
\end{abstract}

KeyWords: rhetoric, art of persuasion, media

\section{Giriş}

Etkili konuşma sanatı olarak nitelendirilen retorik, temelleri çok eskilere dayanan ve günümüze kadar ulaşan, ikna edici unsurları içinde barından akademik bir disiplindir. Retorik Antik Yunan'da Platon ve Aristoteles gibi düşünürlerin anlayışları doğrultusunda şekillenmiş, çeşitli türlere ve unsurlara ayrılarak bugünkü halini almıştır. Bu bağlamda politik, adli ve törensel türle eşleşen ikanın üç kanıtı olan ethos, pathos ve logos, retoriğin temel unsurlarını 
oluşturmakta ve bu sanatın icracısı olan hatibin meziyetlerinde şekil bulmaktadır. Başarılı bir retorik sanatının gerçekleşebilmesi için hatibin ele aldığı konuyu işlemesindeki becerisiyle muhatabı ikna etmesi beklenir. Bu ikna etme girişimde hatip, ethos pathos ve logos birlikteliği ile argümanlarını oluşturarak muhatabına aktarır. Bu anlamda günümüzde medyada da birçok argüman hedef kitleyi ikna edici nitelikte hazırlanarak kullanılır. Dolayısıyla medyanın gösteri kültürü, retorik sanatının icra edilebileceği uygun bir sahnedir. $\mathrm{Bu}$ bağlamda televizyon sunucularının kayıp arama, çocuk istismarı, evlilik vaadiyle dolandırılma, kaçırılma, kadın-erkek cinayetleri gibi konularda tarafları konuk olmaya ikna etmesi, gerçekleri itiraf etmelerini sağlaması, yıllardır açılamayan olayların perde arkasını açıklığa kavuşturması ve gün yüzüne çıkarması gibi durumlar inandırıcılıkları doğrultusunda verdikleri güvenle doğrudan ilintilidir.

Müge Anlı 2008'den bu yana "kurgu olmayan reality show" olarak nitelendirilen Müge Anlı ile Tatlı Sert programında hafta içi her gün canlı yayında yaklaşık 4 saat boyunca kullandığı yöntemle geçmişte kalmış olayların taraflarını ikna ederek ekrana çıkarmakta, verdiği güven ve kullandığı ikna gücü, empati ile kişileri başarıyla konuşturmakta ve neticede pek çok olayı çözüme kavuşturmaktadır. Bu çalışmanın temel sorusu Anlı'nın bunu başarırken hangi retoriksel unsurları nasıl kullandığıdır. Olayların başlangıcından çözüme ulaştırılana kadar geçen süreçte, Müge Anlı'nın yaklaşımları, bakış açısı ve kanıtlar sunmasıyla olaylar

işlenmektedir. İşte bu süreçte ethos, pathos ve logos'u etkin bir şekilde kullanan Anlı, ikna sanatının mahir icracılardan biri sayılabilir. Çalışmada retorik analiz yöntemi kullanılacak ve bu anlamta ethos, pathos ve logos unsurlarının nasıl uygulandığı tespit edilecektir.

$\mathrm{Bu}$ çalışmada retoriğin teorik zemininden yola çıkarak bir analiz gerçekleştirilmiş ve belirli bir olaya yoğunlaşarak durum çalışması yapılmıştır. 4-10 Şubat 2020 tarihleri arasında “evlilik vaadiyle dolandırılma” konusu takip edilmiş, Anlı’nın ortaya koyduğu yaklaşımlarda ethos, pathos, logos irdelenerek ikna sanatının nasıl kullanıldığını ortaya koymak amaçlanmıştır.

\section{Retorik Sanatının Doğuşu}

Temeli antik çağlarda atılan retorik, günümüzde iletişim çalışmalarında da yaygın olarak kullanılan akademik bir disiplindir. Konuşma sanatı, etkili hitabet ve belegat gibi isimlerle de tanımlanan retoriğin ilk kez Platon ve Aristoteles tarafından geliştirildiği ve birçok kavram etrafında şekillendiği bilinmektedir (Bıçakçı, 2012: 334). Geniş anlamıyla hayatın içinde etkin varlık gösteren bireylerin yürüttükleri konuşma sanatı olarak ele alınan retorik, dar anlamıyla çeşitli düşüncelerin ve dil sisteminin adıdır. Retorik hem bir metin üretiminde hem de metnin 
incelenmesinde kullanılır. Aynı zamanda retoriğin "hakikati ortaya çıkmak" gibi bir gayesi de bulunur. $\mathrm{Bu}$ sebeple argümantasyon oluşturulabilme, yani delillendirme, dayanaklandırma veya gerekçelendirme yollarına başvurur (aktaran Temir, 2019: 71-72).

Eski Yunan'da ortaya çıkan retorik, sosyal ve siyasal konularla ilgili hem etkili nutuk atmanın hem de bunu diğerlerine öğretmenin imkanlarını bulmaya çalışan önemli bir bilim dalı haline dönüşmüş ve üst düzey sınıfların hizmetine sunulmuştur. Retorik ile ilgili bilinen ilk metin Platon'un "Gorgias" diyaloğudur. Gorgias'ın bu diyalogda "sözle ikna etme gücü” olarak retoriğe işaret ettiği görülmektedir. Platon'un ise retoriği "bir kandırma ya da aldatma işis" olarak tanımladığı söylenmektedir (Altınörs, 2011: 82). Platon'un eleştirdiği ve ideal devlet için uygun bulmadığı retoriği, daha sonra öğrencisi Aristoteles ele almış ve teorik bir zemin olarak sistemleştirmiştir (Tabak, 2015: 77). Dolayısıyla Platon'dan farklı olarak Aristoteles, retoriği hem önemsemiş hem de bir teori haline getirerek kuramsallaştıran ilk filozof olmuştur (Nas, 2013: 19).

Retorik antik Yunan'da ortaya çıktıktan sonra ikna etme araçlarından biri olarak görülmeye başlanmıştır. Zira Yunan şehir devletlerinde, retorik aracılığıyla kitlelerin sadece etkilenmediği aynı zamanda ikna olup hareke geçtiği de gözlemlenmiştir. Bu açıdan retoriğin gündelik hayat içindeki yerinden esinlenerek bir ikna aygıtı olarak ortaya çıktığı, dolaysıyla bir gereksinim olduğu düşüncesi dikkat çekmektedir (Nas, 2013: 19). Aristo’ya göre retorik “tam anlamıyla inandırma tarzıyla ilgili”dir (Aristoteles, 1995: 35). Retorik, ikna edilmek istenen dinleyicinin değerleri, bağlılıkları ve inanışları üzerinden temellendirilen bir disiplindir ve bu anlamda ikna edici argümanlara odaklanmaktadır (aktaran Nas, 2013: 19). Aristo için başarılı bir hatip olmak argümanları iyi anlamaktan geçmektedir. Bununla beraber dinleyicinin duygularını ve karekter bileşenlerini de çözmek zorundadır (Koçak, 2013: 8). Hatibin dinleyicinin kültürel farklılıklarını bilmesi ve buna uygun şekilde argümanlarını geliştirmesi ikna sanatının temelini oluşturur (Byers, 2009: 11-12). "Hitap etme yeteneği ve ikna etme becerisi" (Zafer, 2017: 4) olarak nitelendirilen retorik, herhangi bir konuyla ilişkilendirilmez, yani retorik her türlü konuyu kapsamaktadır (Aristoteles, 1995: 37).

Günümüzde bireylere tanıdık gelen yeni bir dünyadan ve gerçeklikten bahsedilebilir. İşte bu yeni gerekçeklik televizyon ve sinema aracılığıyla görüntü diliyle sağlanmaktadır. Dolayısıyla dinleyicilerin ilgisini çekmek amacıyla heyecanlandıran, şok etkisi yaratan hem kötü hem de güzel duygular, bu yeni retorik sahnesinde yansitılır olmuştur (Köklüdağ, 2016: 206). Aristo'nun da belirttiği gibi, “İnandırma bir tür gösteridir, çünkü bir şeyin gösterilmiş olduğunu düşündüğümüzde tam olarak inanmış oluruz. Hatibin gösterdiği bir örtük tasımdır, 
buysa genel olarak inandırma tarzlarının en etkili olanıdır." (Aristoteles, 1995: 5). Diğer taraftan Michel Meyer'e göre de retoriğin gerçekleşebilmesi için gereken hatip ve dinleyici dışında üç temel unsurdan biri "medya"dır. Medya; konuşabilen veya yazılan bir dildir. Bu dil, görsel veya resim dili de olabilir. Televizyon ve sinema, konuşma, müzik ve görüntü dili aracılığıyla etkisini gösterir ve güçlerini bunlardan alırlar (Meyer, 2004: 10).

Son olarak retoriğin ikna edici söyleminde üç türden söz edilebilir. Bu türler amaca, zamana ve dinleyici durumuna göre belirlenmektedir. Politik (müzakereci), hukuki (adli), övgü/yergi (epideiktik/törensel) söylevler, bu üç türü oluşturmaktadır (Bıçakçı, 2012: 335; Karaman, 2019).

\subsection{Retoriğin Türleri}

Yapılan çalışmalarda retoriğin türleri konusunda kabul görmüş üç tür bulunmaktadır. $\mathrm{Bu}$ bağlamda politik (müzakereci), adli (hukuki), epideiktik (törensel) retorik türleri hakkında, kayda değer bir kesim tarafından değerlendirilme yapılarak fikirbirliğine ulaşıldı̆̆ söylenebilir (Zafer, 2017: 7). Politik/müzakereci söylev; faydal1-faydasız, iyi-uygunsuz, adli/hukuki söylev; hak-haksızlık, adalet, törensel/epideiktik söylev ise ayıp-kusur, iffet, meziyet gibi konular çerçevesinde ele alınır (Zeybek, 2015: 132).

Politik/müzakereci söylevi benimseyen hatip, var olan bir eylem yolunun uygun olup olmadığı veya zararlı olduğunu anlatmaya çalışır (Aristoteles, 1995: 44). Aristo’ya göre özellikle politik söylevde hatip, dinleyicilere kendi karakterini doğru göstermeye ve dürüst duygular beslediğine inandırmaya çalışır. Böylece etkisini daha çok artırır. Tabi burada dinleyicilerin de hatip gibi düşünmesi, onun düşünce tarzını benimsemesi ve karakterini doğru görmesi gerekir (Aristoteles, 1995: 97). Bu konuşma türünde hatip, bireylere bir şeyi yapma ya da yapmama konusunda yönlendirme vasfi gösterir. Hatibin amacı, sözü ettiği konuyla ilgili eylemin uygun veya zaralı olduğunu anlatma dışında, ayrıca kabul ettirmek istediği ve yararlı olduğunu savunduğu öneriyle ilgili ana fikre yardımcı olacak her türlü bilgiyi de aktarmaktır (Karaman, 2019: 44-45). Bu anlamda taraflar bütün diğer noktaları ana konuya bağlı olan şeyler olarak sunarken, bir insanı öven veya saldıran olarak onun onurlu ya da onursuz olduğunu kanıtlamaya çalışır. Tüm bunlar diğer düşünceleri desteklemek amacıyla yapılır (Aristoteles, 1995: 44).

Adli/hukuki retorik suçlu olduğu düşülen insanların suçlarını ortaya çıkarmak ya da suçsuz olduğunu düşünülenleri aklamak amacıyla yapılan söylev türüdür. Kaynağı ise kanunlardan ve doğrulardan gelir (Çodur, 2017: 60). Adli söylevde "Bir taraf diğer tarafı suçlarken, diğer 
taraf da kendini savunmaktadır" (Karaman, 2019: 45). Bu retorik türü özünde adalete dayanmaktadır. $\mathrm{Bu}$ yüzden de birinin suçluluğu ya da masumiyeti hakkında yargıda bulunulduğu için genellikle mahkemelerde sürdürülen kovuşturmalarda kullanılır (Bıçakçı, 2012: 336). Ancak adaletin yalnızca mahkeme salonlarında tartışılan bir konu olmadığı gerçektir. Yaşanan şeylerle ilgili doğru-yanlış saptaması yapmaya çalışırken, her aşamada hukuki konular doğrultusunda usavurum yapılır. Elde olan kanıtlardan yola çıkarak mantıklı çıkarımlara ulaşılmaya çabalarken, adalet hakkındaki düşünceler ve inançlar devreye girer (Koçak, 2013: 4). Son olarak belirtilmelidir ki; hukuki hatibin bir tarafın suçlu olup olmadığıyla ilgili bir görüş beyan edebilmesi için iyi bir karakter analizi gerçekleştirmesi gerekir. Hem insanların düşünceleriyle yakından ilgilenmeli hem de toplumun adalete dair fikirlerini yakından takip etmelidir (Karaman, 2019: 45).

Törensel/epideiktik retorik ise kamuya açık bir alanda bir tarafın diğer tarafı övme ya da kötüleme üzerine gerçekleştirdiği bir hitabet türüdür. Bu hitabet türünün ahlak ve erdemle ilgili olduğu belirtilmektedir (Çodur, 2017: 61). Bir kişi övülürken ya da kötülenirken, o kişinin onurlu olup olmadığı ispatlamaya çalış1lır ve tüm düşünceler bu amaç etrafinda şekillenir. Epideiktik söylevde cesaret, dürüstlük veya onur gibi değerler vurgulandığı için oldukça önemli bir yere sahiptir (Karaman, 2019: 45).

Aristoteles'e göre retoriğin bu üç türü farklı zamana göndermede bulunur. Politik/müzakereci retorik gelecekle ilgilidir. Birinin lehine ya da aleyhine konuşulduğu zaman, bundan sonrası kastedilir. Adli/hukuki retorik geçmişle ilgilenir; gerçekleşmiş bir olayla ilgili biri diğerini suçlar, diğeri de kendini savunur. Törensel/epideiktik retorik ise içinde bulunulan zamanla ilgilidir. İnsanlar aynı zamanda gelecekle ilgili tahminlerde bulunmayı ve geçmişi hatırlamayı çoğu zaman daha yararlı görse de aslında şimdiki zamanla ilgi durumu göz önünde bulundurarak birini över ya da suçlar (Aristoteles, 1995: 44). Aristoteles için bir konuşmanın "sac ayağı"nı oluşturan üç unsur vardır: "hatip, konu ve muhatap". Bir konuşmada hedef muhataptır ve bu üç tür muhataba yönelik tasnif edilir. Ayrıca Aristoteles’in tasnif ettiği bu üç türün üç terimle ilişkilendirildiği görülmektedir: ethos, pathos, logos (Altınörs, 2011: 88). "Retoriğin üç türü olan bu politik, adli ve törensel retoriğin temelinde ikna ve iknanın üç kanıt1, ethos, pathos ve logos bulunmaktadır" (Çodur, 2017: 63).

\section{2. Retorik Sanatında İknanın Üç Kanıtı}

İknanın çok eski zamanlardan beri hayatın içinde var olan bir kavram olması, iletişimde de eski bir disiplin olarak kullanılmasını sağlamıştır. İnsanlar diğer insanlarla olan ilişkilerini güçlendirebilmek, yaşamlarını sürdürebilmek ve sosyalleşebilmek amacıyla ikna iletişimine 
her daim gereksinim duymuşlardır (Zafer, 2017b: 2). Retorik disiplininde iknaya ait temel unsurlar, sistematik bir şekilde istenilen amaçlara ulaşma çabasını doğrultusunda üçe ayrılmaktadır. $\quad \mathrm{Bu}$ unsurlar konuşmacının kontrolünde yeniden biçimlendirilir ve şekillendirilir. Böylece ikna edici bir etkiye ulaşılabilir (Çam, 2015: 16).

$\mathrm{Bu}$ üç temel unsur, Aristoteles'e göre inandırmayı etkileyen üç yoldur. Bunlar: (1-logos) “mantıksal olarak düşünebilme” ya da "mantıksal argümanlar", (2-ethos) "insan karakterini ve erdemini çeşitli biçimleri içinde anlayabilme" ya da "güvenilirlik", (3-pathos) "coşkuları anlayabilme" ya da "duygusal argümanlar" olarak belirtilir. Retoriğin içindeki bu üç unsurdan birini diğerinden daha önemli görmek mümkün değildir. Başarılı bir söylevde, hatibin kullandığı dilin özellikleri ayırt edilemez. Dolayısıyla retorik içerisinde ethos, pathos ve logos girişten sonuca kadar girift bir şekilde varlık gösterir. Ethos, pathos ve logos'un uyumlu bir şekilde kullanılması iknanın özünü oluşturur. Bu üç unsurun önemi ve geçerliliği günümüzde de halen devam etmektedir (Aristoteles, 1995: 38; Güzel, 2016: 37; McCormack, 2014: 132; Tabak, 2015: 84; Zeybek, 2015: 129).

Aristo üç retorik türünün her birinde, üç ikna kanıtı olarak nitelendirilen ethos, pathos, logos’tan birinin daha baskın olduğunu belirtmektedir. Buna göre hukuki türde, ikna etmeyi kanıtlama yoluyla gerçekleştirdiği için logos, yani mantık ağırlıktadır. Politik türde hatibin mizacı, tavırları, faziletleri inandırıcılığı artırdığından dolayı ethos daha baskındır. Törensel tür ise dinleyicilerin duyguları uyandırılmaya çalışıldığ 1 için pathos merkezlidir (Altınörs, 2011: 88).

Ethos, pathos ve logos kavramlarını daha detaylı bir şekilde ele almak incelenecek konuyu daha iyi anlamamıza yardımcı olacaktır.

\section{2. 1. Ethos}

Ethos, hatibin kişisel özelliklerini ve konumunu ifade eder. Aristo'a göre ethos sözcüğü etikten türemiştir. Bunun anlamı da ahlaktır; böylece Aristo konuşmacıyı ahlaki temellere dayandırır ve iyi insanlara diğerlerinden daha kolay inanıldığını belirtir (Güzel, 2016: 38; McCormack, 2014: 136).

Bireyin karakteri, yani insani özellikleri sahip olunan en etkili inandırma yolu olarak görülür. Hatip toplum tarafından iyi ve doğru kabul edilen bir davranış sergilediğinde otorite sağlar. Çünkü hedef kitlenin güvenini kazanmış olur. Bunda hatibin konumu, giyimi, vücut dili, konuşma biçimi, ses tonu gibi birçok etmenin etkisi olduğu söylenebilir (Tabak, 2015: 81-82). Dahası sezgili, alçak gönüllü, şefkatli, sorumluluk alan, bilge, dürüst, adil ve saygılı gibi 
birçok özelliğin hatipte bulunması gerekir (Zafer, 2017: 6). Sayısız nitelik, hatibin dinleyici üzerindeki ikna edici güvenirliğini etkileyebilir. Hatibin mesleki ve sosyal statüsü, zekas1, cinsiyeti, ırkı, dini inancı, sosyoekonomik durumu, psikolojik yapısı, eğitimi de anlatıyı etkileyen diğer hususlardır. Hiç yalan söylemediği bilinen kişilerin söylediklerine daha fazla güven duyulmaktadır. Dolayısıyla kaynak söylevin güvenilirliğini doğrudan etkilemektedir. $\mathrm{Bu}$ anlamda ahlakın herkese örnek olması gerekir (Güzel, 2016: 48-51; McCormack, 2014: 37-138; Meyer, 2004: 11-12). Buna göre Senem Zafer'in, ethos’un güvenilirlik özelliğinin reklam metinlerinde hangi cümlelerle kullanıldığına dair ortaya koyduğu bulgular, örnek teşkil etmesi açısından önemlidir. Zafer, Sözcü Gazetesi'nin reklam sloganında tanınan bir kişilik üzerinden ethos'un kullanıldığını şu cümle ile aktarmaktadır: “Türkiye'de güven denince akla gelen ilk isim.... Uğur Dündar Sözcü'de” (2017: 7). Özetle Güzel'in de ifade ettiği gibi:

Sosyal statü ile metne hayat veren, risk alan, kaynăg belirten ya da kendisi kaynak olan, dinleyicide oluşabilecek yarglları ön gören, onları dinleyiciden önce ifade ederek bu olumsuz yargllarl ortadan kaldıran, kendi özelliklerini alternatif açıklamalarla pekiştiren, yaşadı̆̆ ya da dinlediği olayların gönülsüz şahidi, olağanüstü duruma inanmadığını belirten ama yaşadığını açıklayamayan sözde cehaletiyle ve olaylart test edip onaylamastyla anlatının güçlü unsuru olan ethos, dinleyicide oluşan ikna etkisinin mahir icracısıdır (2016: 56-57).

Aristoteles için ethos, ikna için esastır; çünkü genel olarak tüm konularda adil davranan insanlara diğerlerinden daha fazla ve daha hızlı inanılmaktadır (Byers, 2009: 10). Meyer'e (2014: 26) göre “ethos genel olarak dinleyicinin özdeşleştiği biri gibidir”. Günümüzde ise ethos, ünlü ve itibarlı kişilerle eşleştirilir (Zafer, 2017: 6).

\section{2. 2. Pathos}

Pathos'un en belirgin özelliği dinleyicilerde belli bir ruh hali yaratmaktır. Bu durum hislerle ve duygularla ilgilidir. $\mathrm{Bu}$ anlamda hatibin insan ruhunu iyi analiz edebilmesi gerekir. Dolayısıyla pathos bir “duygu psikolojisi”dir. Tartışılan konuyla ilgili hedef kitlenin duygusal durumunu kontrol altına almak için duygunun detaylı psikolojisi ortaya konulur (Koçak, 2013: 6). Pathos dinleyicinin duygusal ve psikolojik yanlarıyla bağlantılı olarak olayları anlamlandırmasıyla ilgilidir. Bu bağlamda duygusal çekiciliğin adıdır (Başarır, 2016: 712). Hatibin değerlendirmeleri hem akli hem de duygusal olarak gerçekleşmektedir. Böylece dinleyici duyguları aracılığıyla hatip ve konu üzerinde bir hüküm geliştirmektedir. Dinleyicide oluşan hükümlerin ardından, anlatılanlar doğrultusunda duygusal bir değişim ve dönüşüm ortaya çıkabilir. İşte bu durum meydana geldiğinde, dinleyicinin hem hatibe hem de anlatılan konuya karşıya var olan tutumunda olumlu bir yaklaşım görülür. $\mathrm{Bu}$ yaklaşım 
dinleyicinin anlatılanları doğru kabul etmesine dayanmaktadır. Dolayısıyla konuşmacının performansı, hedef kitlenin sadece aklına değil aynı zamanda duygularına da hitap eden bir çaba birlikteliğidir (Güzel, 2016: 107).

Aristoteles'e göre konuşmanın dinleyicinin coşkularını hareket geçirmiş olması, inandırmanın gerçekleşmesini sağlayabilir (Aristoteles, 1995: 38). Bu bağlamda retorikte pathos unsuru, hedef kitlenin görüşlerini değiştirmek için duygularına hitap etmektedir (Zeybek, 2015: 130). Duygular, önceden var olan ruh halini içeren sayısız uyarandan etkilenebilir. (McCormack, 2014: 141). Bu duygular aynı zamanda iddia edilen konunun ispatına yönelik kanıtlardır. $\mathrm{Bu}$ duygusal kanıtlar pathos olarak değerlendirilir ve hatip kendi hayatından örnekler vererek pathos'u kullanabilmektedir. Canan Karatay'ın konuşmasını retorik ile analiz eden Ayşe Banu Bıçakçı, Karatay’ın kendi deneyiminden yola çıkarak pathos'a başvurduğunu belirtmektedir. Karatay: "İki hastam bu olayı bilmeden doğal olarak dediler ki ben uyuyarak kilo verdim" cümlesiyle kendi hayatından örnek vermiş ve pathos'u kullanmıştır (Bıçakçı, 2012: 337-355).

\section{2. 3. Logos}

Logos kelime olarak İngilizce "logic” yani mantık sözcüğünden türemiştir. Aristo'ya göre retorik alanında kullanılan "logos", mantığa dayalı akıl yürütme durumudur. Logos hatibin anlattıklarını mantıki temellere bağlamasıdır. Yani burada sorgulanması gereken şey akıl ve mantık arasındaki ilişkidir. Hatibin söylediklerini tutarlı bir yapıda kurgulaması beklenir (Güzel, 2016: 38-39; Zeybek, 2015: 131). Logos'ta dinleyicinin mantıksal tarafi dikkate alınırken, aynı zamandan kanıtlar sunmaya gayret edilir. Dinleyicinin istatistikler, örneklemeler, vaka analizi vb. gibi rasyonel etkenlerle algılama yeteneği geliştirilmeye çalış1lır ve böylece bir sonuca ulaşılmaya odaklanılır (Çam, 2015: 28). Örneğin Erkam Temir çalışmasında incelediği kişinin logos'a ağırlık verdiğini şu cümleden anlamıştır: "Burada şimdi size anlatacağım tüm inkar edilemez kanıtlar bir araya toplanmıştır. Belgeler, şemalar ve ilişkiler" (2019: 163). şeklinde devam eden argümanlar, söz konusu şahsın konuşmasını logos'la desteklediğini göstermektedir. Çünkü cümle içerisinde somut kanıtlardan bahsedilmektedir. Belirtmek gerekir ki logos'un bu yönü ile hem kaynağa (ethos) hem de duyguya (pathos) yönelik bir göndermede bulunulmaz. Söylemin kendi içinde oluşan kanıtlar, konuşmada geçen sorulara kaynaklık etmektedir (Başarır, 2016: 712-713).

Ortaya konulan konuşma her yönüyle bir performans olarak değerlendirilebilir. Bu sebeple kullanılan jest ve mimikler, anlatı anında sergilenen tavır ve davranış, logosu etkilemektedir. Anlatıdaki sözcükler ve ifadelerin tutarlılığı ve mantığa uygun bir şekilde oluşturulması, performans sırasında rahatlıkla ortaya konulabilir. Ayrıca bu esnada anlatının içeriğine göre el, 
kol ve yüz hareketlerinin kullanılması, sesin alçaltılıp yükseltilmesi gibi unsurların inandırıcılığı etkilediği söylenebilir (Güzel, 2016: 57). İyi düşünülerek tasarlanmış logos argümanları, ethos'un -yani hatibin- başarısına da başarı katacaktır. Hatip logosu başarılı bir şekilde kullandığında, dinleyiciyi ikna etme konusunda da aynı başarıyı gösterecektir. Bu yüzden logos ve ethos birbirine sıkı bir biçimde bağlı, iknanın iki temel unsurudur. Hedef kitleyi çok güçlü kanıtlarla ikna etmeye çalışan logos, akıldaki soru işaretlerine cevap verirken, farklılıklarını da koruyarak açıklamalarda bulunur (Çodur, 2017: 68). Özellikle alternatif açıklamalar yapabilmek için canlı performans sergilendiğinde, hedef kitle üzerinde olumlu etki oluşmaktadır. Böylece hatip verilen detaylar aracılığıyla gerçek bir olayı anlattığına dair iddiasını kanıtlamış olur. Ayrıca dinleyici konuyla ilgili detayları keşfettiğinde, anlatının güven duyulması gereken bir yapıda olduğu bilincine erişir (Güzel, 2016: 73-81).

Sonuç olarak Aristoteles, yukarıda aktarılan ve "iknanın üç kanıtı" olarak değerlendirilen ethos, pathos ve logos'un hatip tarafından kullanılabilmesi için gerekli meziyetleri şöyle özetlemektedir: (1) "adetler ve faziletler hakkında bilgisi olmalıdır", (2) "Muhatabında çeşitli teessürler ya da şiddetli duygular uyandırmanın yollarını bilmelidir"; (3) "Argümantasyon yapabilecek durumda olmalıdır" (Altınörs, 2011: 88) ve başarılı bir retorik bu üç unsurun birlikteliğinden doğar. Öyle ki tartışılan konu işlendikten sonra, anlatıya dair aksi bir durum söz konusu olsa dahi dinleyicilerin fikirlerini değiştirmeye yetmez (Tabak, 2015: 84).

\section{2.“Müge Anlı ile Tatlı Sert” Programında İkna Sanatının Çözümlemesi}

\section{1. Araştırmanın Amacı ve Önemi}

2008 y1lından bugüne kadar devam eden ve yüksek izlenme oranına² sahip olan "Müge Anlı ile Tatlı Sert" programı, gündüz kuşağı programları arasında önemli bir yer edinmektedir. "Kurgu olmayan reality show" olarak ifade edilen programda, günde yaklaşık 4 saat boyunca kayıp arama, çocuk istismarı, evlilik vaadiyle dolandırılma, kaçırılma, kadın-erkek cinayetleri gibi vakalar işlenmektedir. Program, çözüme kavuşturduğu olayların sayısıyla da önemli bir yerde durmaktadır. $\mathrm{Bu}$ anlamda programın içeriğini oluşturan olaylar toplumda yaşanmakta, yani toplumdan beslenmektedir. Dolayısıyla ham maddesi toplumdan sağlanan olaylar, aynı zamanda toplumu da etkilemekte, hatta topluma birtakım katkılar sunmaktadır (Küçükcan, 2019: 13-14).

$\mathrm{Bu}$ katkılar sunulurken, verilen mesajlarda ikna edici söylemlerde bulunulmakta ve bu

\footnotetext{
2 https://www.sabah.com.tr/magazin/2020/06/25/en-cok-izlenme-payi-muge-anli-ile-tatli-sertte ve https://www.dizidoktoru.com/tv/muge-anlidan-bir-rekor-daha-h4401.html linklerde yer alan basında çıkan haberlerden yararlanılmıştır.
} 
söylemler programın sunucusu Müge Anlı'nın dilinden aktarılmaktadır. Dolayısıyla nevi şahsına münhasır bir kişilik olarak Anlı'nın kullandığg argümanlar, dinleyicinin fikirlerini değiştirici ve farklı davranışlara yönlendirici nitelikte olabilir. Bu durum bir hatip olarak Anlı'nın ifadelerinin güvenirliğine de işaret etmektedir. Zira Mediacat tarafından gerçekleştirilen araştırmada “Celebrity Güven Endeks'i raporuna göre, 2017 yılında 1. Sırada yer alan Müge Anlı'nın, 2019 yılında 3. sırada yer alması (Mediacat, 2019), aslında onun inandırıcılık ve ikna edicilik açısından ne kadar önemli bir yerde durduğunu göstermektedir.

Diğer taraftan programda sosyal sorumluluk bilinciyle oluşturduğu projeler, Anlı'nın duyarlığı kişiliğini ön plana çıkarmaktadır. Sevgi izi, patibuldular, aşevi, engelliler için akülü sandalye, Doğu Anadolu'da kitabı olmayan okullar için kitap sağlama gibi pek çok projeye imza atan Müge Anlı, bu yönüyle sezgili, vicdanlı, merhametli, şefkatli ve sorumluluk alan karakteri ile göz önünde bulunmaktadır. Kısaca bu durum Aristo'nun ifadelerinde de olduğu gibi ahlaki temellere dayanan iyi bir insan özelliğine vurgu yapmakta ve böylece ethos yönü güçlü olan bir hatibe gönderme yapmaktadır. Ayrıca Zafer'e (2017: 6) göre ethos, son zamanlarda medyada yer alan ünlüleri kapsamakta, itibarlı kişilerle eşleşmektedir. Bu anlamda Anlı’nın ünlü ve itibarlı bir kişilik olduğu söylenebilmektedir.

Müge Anlı'nın güvenilir ünlüler listesinde üst sıralarda yer alması onun ethos yönünün (kaynağın güvenilirliği) olduğu düşüncesini uyardırmakta, hatta diğer iki unsurun da olabileceği öngörüsünde bulunmamıza sebep olmuştur. Bu yaklaşımlar 1şığında çalışmanın amacı, belli bir olay doğrultusunda Anlı'nın kullandığı argümanlara yönelmek ve bu argümanlarda retoriksel unsurların olup olmadığını iredeleyerek, varsa nasıl kullandığını ortaya koymaktır.

\section{2. Araştırmanın Sınırlılıkları}

Bu çalışmada 4-10 Şubat 2020 tarihleri arasında "evlilik vaadiyle dolandırılma" iddiasıyla başvuran, İzmir'de yaşayan Adile Yeşilgöz ve babası Mehmet Hayri Yeşilgöz'ün konu alındığı, ancak sonrasında bu kişileri aşarak benzer iddialarla programa dahil olan kişileri de kapsayan toplam 5 program, yani yaklaşık 11 saatlik bir süreç takip edilmiş ve Müge Anlı'nın ifadeleri deşifre edilerek metin olarak kaydedilmiştir.

\section{3. Araştırmanın Yöntemi: Retorik Analiz ve Durum Çalışması}

Çalışmanın başından bu yana anlatılan retorik, akademik bir disiplin olduğu kadar aynı zamanda metodolojik bir çözümleme yöntemidir. Retorik analizinin doğru uygulanabilmesi için retoriğin inandırma ve ikna etme tarzları olan ethos, pathos ve logos'un iyi bilinmesi 
gerekir (Güzel, 2016: 37). Yukarıda detaylı bir şekilde anlatılan ikna ve inandırma unsurları, retorik analiz doğrultusunda uygulanmaya çalışılmıştır.

Çalışmada diğer kullanılan yöntem ise literatürde “case study” olarak geçen ve Türkçe'ye durum çalışması, durum incelemesi, vaka çalışması, örnek olay incelemesi gibi isimlerle çevrilen (Subaşı ve Okumuş, 2017: 419) ve bu çalışmada da durum çalışması olarak nitelendirilen metottur. Esasen Stake'e göre durum çalışması metodolojik bir yöntem değildir, çünkü bir vakayı ele aldığı için ne inceleneceğinin seçimi olarak görülür. Yani burada bir duruma odaklanma söz konusudur. Hangi yöntem kullanırsa kullanılsın tekrarlanabilir ölçümler yapılmasından dolayı durum çalışması gerçekleştirilebilir (Stake, 2003: 134). Creswell ise Stake dışındaki diğer düşünürlerin durum çalışmasını, kapsamlı bir araştırma stratejisi veya bir metodoloji olarak belirttiklerini ifade ettikten sonra kendi duruşunu sergiler. Ona göre durum çalışması; bir metodoloji, nitel bir araştırmada bir tasarım türü ya da bir çalışma nesnesi olmasının dışında araştırmanın bir ürünüdür. Durum çalışması, araştırmacının bir zaman içinde sınırlı bir sistemi yani vakayı içine alan ve birden fazla bilgi kaynağını içeren, ayrıntılı ve derinlemesine veri toplama aracılığıyla yapılan nitel bir yaklaşımdır (Creswell, 2007: 73).

Durum çalışmasıyla ilgili yaklaşımlar içerisinde önemli bir yeri olan Yin'e göre ise durum çalışması, veri toplama ve veri analizine yönelik özel yaklaşımlar barındıran tasarım mantığıyla her şeyi kapsayan bir yöntemdir (Yin, 1984: 13). Gerring ise bu metodolojiyi durum çalışması ve çapraz durum çalışması olarak ikiye ayırır. Durum çalışması tek bir durumu incelerken, çapraz durum çalışması birden fazla durum içerir. Gerring, bu iki seçeneği birbirine rakip görmek yerine, tamamlayıcı olarak görmek gerektiğini ifade eder. Ona göre araştırmacılar her ikisini de yapabilir ve tartışmalı olarak her iki kanıt tarzını ele alabilir (Gerring, 2007: 13).

Miles ve Huberman (1994: 25-26) durum çalışmasının sınırlarını, merkez-çevre ilişkisiyle anlatmaktadır. Örnekler üzerinden durum çalışmasını anlatan Miles ve Huberman, durumun "kalbine" (merkez) odaklanılması gerektiğini, ancak bunu yaparken kalbin çevresini yani sınırlarını da dikkate almanın önemini vurgulamaktadır. Odaklanılan konu bazen bir birey, bir grubun temsilcisi (örneğin bir kadın, bir müdür), ama daha sık olarak belirli bir olay, durum, program veya etkinlik olabilir (Hancock ve Algozzine, 2006: 15).

Görüldüğü gibi literatürde durum çalışmasıyla ilgili farklı düşünürlerin farklı yaklaşımları vardır. $\mathrm{Bu}$ farklılıklar araştırmanın desenleri konusunda da devam etmektedir. Durum çalışmasının farklı düşünürler perspektifinden bir araya getiren Subaşı ve Okumuş bir tablo 
oluşturarak yaklaşımları şu şekilde çıkarmıştır:

\begin{tabular}{|c|c|}
\hline Araştırmacı & Durum çalışması desenleri \\
\hline & -Gerçek (instric) \\
\hline \multirow[t]{2}{*}{ Stake (2005) } & -Araçsal (instrumental) \\
\hline & -Kolektif \\
\hline \multirow{3}{*}{ Merriam (1998) } & $\begin{array}{l}\text {-Disiplin yönelimli, etnografik, tarihsel, } \\
\text { psikolojik, toplumsal }\end{array}$ \\
\hline & $\begin{array}{l}\text {-Genel amaçlı, betimleyici, yorumlayıcı, } \\
\text { değerlendirmeci }\end{array}$ \\
\hline & -Çoklu durum \\
\hline \multirow[t]{3}{*}{ Bassey (1999) } & -Teori oluşturan ve teori test eden \\
\hline & -Hikâye anlatan ve resim çizen \\
\hline & -Değerlendiren \\
\hline \multirow[t]{4}{*}{ Yin (1984) } & -Bütüncül tek durum deseni \\
\hline & -İç içe geçmiş tek durum deseni \\
\hline & -Bütüncül çoklu durum deseni \\
\hline & -İç içe geçmiş çoklu durum deseni \\
\hline \multirow[t]{3}{*}{ Yin (1994) } & -Keşfedici \\
\hline & -Açıklayıcı \\
\hline & -Tanımlayıcı \\
\hline
\end{tabular}

Tablo: 1 Durum çalışması Desenleri (Subaşı ve Okumuş, 2017: 422)

$\mathrm{Bu}$ desenlerden Yin'in “bütüncül tek durum deseni” bu çalışma için uygunluk göstermektedir. Bu desen, analiz edilecek tek bir birim ya kendine özgü ya da aykırı bir durum, "çok iyi formüle edilmiş bir teorinin test edilmesinde kullanılan bütüncül tek durum" şeklinde ifade edilmektedir (Subaşı ve Okumuş, 2017: 422). Çalışmada tek bir birim (Müge Anlı) seçildiği, kendine özgü bir durum çalışıldığı ve bir teori olarak değerlendirilebilecek ethos, pathos ve logos test edildiğinden, "bütüncül tek durum deseni" benimsenmiştir. 


\section{4. "Evlilik Vaadiyle Dolandırılma" Olayı Durum Çalışması}

\subsection{1. Örnek Olay Özet}

İzmir'de yaşayan Adile Yeşilgöz ve babası Mehmet Hayri Yeşilgöz programa 4 Şubat 2020 tarihinde katılmıştır. Adile Yeşilgöz (25) yaklaşık 6 ay önce yaşadığı dolandırılma hikayesini anlatmak için programa başvurmuştur.

Adile sosyal medya aracılığıyla tanıştığı Ihsan Çapar isimli kişiyle evlenmeye karar verir. Aslında İhsan Çapar resmi nikahlı ve 4 çocuk babasıdır. Fakat kendini Adile'ye dul olarak tanıtır. Kısa süre sonra İhsan Çapar, Adile'nin babasıyla tanışmaya gelir. O gün yanında gelen ve kendisini hoca olarak tanıtan fakat sonradan İhsan'ın abisi olduğu öğrenilen kişi, evin altında gömü, evde ise büyü olduğunu söyler. İhsan Çapar ve hoca lakaplı kişi, Mehmet Hayri Yeşilgöz'den bahçeden toprak getirmesini ister. İhsan Çapar ve hoca lakaplı kişi, bu toprağa bakarak büyünün ve gömünün olduğunu kesinleştirir. Adile ve babası ne olup bittiğini anlamadan kendilerini olayın içinde bulur. Bu gömünün çıkabilmesi ve büyünün bozulması için harekete geçilir. Öncelikle eve bidonlar, çarşaf, mum, çakı gibi şeyler alınır ve bir odaya istiflenir. Adile ve babasından yakmak amacıyla çok miktarda dolar istenir. Ancak dolarlar yakılırsa büyü bozulup gömüden altın çıkabilecektir. Adile ve babası ellerindeki her şeyi satıp, altınlarını bozdurup ve borç alıp, istedikleri doları İhsan Çapar'a verirler. Diğer taraftan büyünün bozulması ve altınların gelebilmesi için namaz borçları ödenmelidir. Yaklaşık 600 rekatlık namaz kılınması talebinde bulunulur. Bu sırada bidonların durduğu odanın kapısı kilitlidir, içeri girmek yasaktır. Çünkü hoca lakaplı kişinin üç harflilerden çocukları olduğu söylenir ve iddialara göre çocuklar bu odadadır. Üstlerine basılmaması gerekir.

Tüm bunlar yapıldıktan sonra İhsan Çapar ve hoca lakaplı kişi, akşam vakti bidon istifli odaya girerek sahtesiyle değiştirdikleri dolarları yakar, bidonların üstüne çarşaf örter, mumu yakar ve Adile ile babasını hiçbir şeye dokunmamak şartıyla odaya çağırır. Odada yere basarken dikkat etmeleri gereklidir. İhsan Çapar bidonların üzerinde örtülü olan çarşafı ucundan kaldırdığında, Adile ve babası bidonları ağzına kadar altınla dolu görür. Yerdeki dolarlar (sahte) ise yakılmıştır. İhsan Çapar altınlardan (temsili gerçek) birini test etmeleri için Adile'nin babasına verir. Mehmet Hayri Yeşilgöz kuyumcuda bu altının gerçek olduğunu öğrenir. Dolayısıyla İhsan'a inanmışlardır. Tüm bu olaylar yaşandıktan sonra Adile ve İhsan nişanlanır. Fakat nişandan sonra İhsan kayıplara karışır. Adile dolandırıldığını o zaman anlamıştır. Kilitli oda açıldığında bir çuvalın içinde sahte altınlar bulunur. Böylelikle İhsan 
Çapar 450 bin değerindeki maddi varlıkla gözden kaybolur. Adile ve babası aylarca şikayette bulunamaz. Şikayet ettiklerinde ise yanlış ifade verirler. Çünkü İhsan Çapar yolun başında bu durumu kimseye anlatmamaları için Kuran-1 Kerim'e el bastırmış, yemin ettirmiştir. Bu çemberin içine girdikleri söylenmiş, dolayısıyla Adile ve babası bu durumu anlattıkları takdirde çarpılacakları ve birbirlerini öldürecekleri gibi ifadelerle korkutulmuşlardır.

Adile ve babası bu olayı Müge Anlı'ya anlattıktan sonra Türkiye'nin dört bir tarafindan benzer şeyler yaşadıklarına dair telefonlar gelmeye başlar. Adeta telefonlar kilitlenir. Olay Adile ve babasını aşmış Türkiye'nin meselesi olmuştur. Bu durumun milyonlarca liralık dolandırıcılık hikayesi olduğu Adile ve babasından sonra ortaya çıkmıştır. Ortada 7,5 milyonluk vurgun vardır. Programa farklı şehirlerden farklı mağdurların katıldı̆̆ı bu konu, dört gün boyunca işlenir. Beşinci gün ise nitelikli dolandırıcılık suçuyla İhsan Çapar cezaevine gönderilir.

$\mathrm{Bu}$ durum din istismarı, duygularla oynama, kandırma, sosyal medyanın zararları, ilim ve bilimin önemi, göz yanılması/sihirbazlık, iki evlilik yapma, iftira atma, define avcılı̆̆ı, gasp, tehdit, sahte para-altın basımı, Suriye'den gelen mağdurların yaptıkları dolandırıcılık vb. konularla dikkat çekmiştir. Dinleyici bu konularla bağlantılı pek çok şeye ikna edilmeye çalışılmıştır. Bu sebeple çalışmada bu durumun incelenmesi, birçok konuya parmak basması açısından önemli görülmektedir.

\subsection{Müge Anlı’nın Olay ile İlgili Konuşma Metni ve Görseller}

Madem evlisiniz de ne gittiniz nişan yaptınız. Hangi ülkede yaşıyorsunuz siz? Türkiye Cumhuriyeti'nde yaşıyorsunuz. Türkiye Cumhuriyeti kanunlarına göre iki tane evlilik yapamiyorsunuz beyefendi. Siz Adile'ye ben evliyim dediniz Adile kabul mu etti, ben kuma mı geleceğim dedi? Yani resmi nikahlı evli olduğunuz halde gidip milletin kızını isteyerek gömü bulacă̆ım deyip parasını dolandırdınız?

Program: 4 Şubat 2020, 34:24

Yukarıda metinde, Müge Anlı'nın canlı yayına bağlanan İhsan Çapar'a evli olmasına rağmen Adile Yeşilgöz ile nişan yapmasına verdiği tepki yer almaktadır. Bu tepkide Türkiye Cumhuriyeti kanunlarına göndermede bulunması, Anlı'nın argümanlarını kanıtlara dayandırdığını göstermektedir. Ayrıca mantıksal kanıtlar sunarken yüzündeki sert ifade ve sesindeki ciddi ton da öne çıkmaktadır. Daha önce de ifade edildiği gibi, anlatının içeriğinin el, kol, yüz hareketleri ve sesin alçaltılıp yükseltilmesiyle oluşturulması inandırıcılı̆̆ etkileyen unsurlardır. Tüm bunlar Anlı'nın logos'u etkin bir şekilde kullandığını göstermektedir. Bu konuşma aynı zamanda retoriğin adli/hukuki türüne girmekte ve geçmiş zamanı içermektedir. 
Beyefendi sizin daha evvel de güveni kötüye kullanma, dolandırıcıllk, yine güveni kötüye kullanma, dolandırıcılık, oto hırsızlı̆̆l, dolandırıcılı, yine güveni kötüye kullanma, dolandırıcılık falan gibi bir sürü şikayetler var sizin hakkınızda. Niye insanlar sizi şikayet ediyorlar böyle?

Program: 4 Şubat 2020, 36:40

Yukarıdaki metinde ise İhsan Çapar ile aynı telefon görüşmesinin devamında, Çapar'ın hakkındaki şikayetler kanıt olarak sunulmaktadır. Stüdyodaki iddiaları yalanlayan Çapar'a elindeki suç dosyalarını sıralayan Müge Anlı, kendi argümanlarını tutarlı bir şekilde oluşturmakta ve İhsan Çapar'ı sorgulamaktadır. Bu soru sonrasında Çapar'ın aniden hattan ayrıldığı görülmektedir. Bu bağlamda argümanlarını sağlam kanıtlara dayandıran Anlı'nın logosu güçlü bir şekilde kullandığı görülmektedir.

Sen niye bir kere zaten sosyal medyadan biriyle tanışırsın. Niye böyle yapıyorsunuz. Arkadaşlar söylüyorum gerçekten bu sosyal medya işlerini bırakın yani. Ĕger bu zaten çok kullanılacak bir şey olsa beni tanıyorsunuz ben kullanırım, ben niye hiç sosyal medya kullanmıyorum. Bir düşünün bakalım yani, ki benim işimle de ilgili, yine kullanmiyorum. Kim olduğu belli değil, ne olduğu belli değil, hangi fotoğrafi koyduğu belli değil, sizin oraya yerleştirdiğiniz fotoğrafları nerede kullanacă̆ belli değil, 50 kere söylüyorum. Çocuklarınızı kullanmayın, kendi fotoğraflarınızı koymayın, aile fertlerinizin fotoğraflarını koymayın. Çocuğunuz okula giderken fotoğraf koyuyorsunuz ne yapıyorsunuz? Bütün dünyaya benim çocuğum şu okula gidiyor diye gösteriyorsunuz. Yarın bir gün sizin çocuğunuza göz koyan biri gelecek, o çocuğu okulun önünden götürebilir. Insan kendi aile fertlerini, nerede yaşadiğını, hangi okula gittiğini, kaç yaşında olduğu, ne olduğunu anlatır mı?

\section{Program: 4 Şubat 2020, 49:25}

Daha önce de belirtildiği gibi hatip var olan bir eylemin uygun olup olmadığını ya da zararlı olduğunu anlatma çabası içerisine girebilir (Karaman, 2019). Aristo'ya göre de hatip bir şeyi yapıp yapmama konusunda dinleyiciyi yönlendirebilir. Böylece politik söylevi benimseyen hatip, kendi karakterini doğru göstermeye çalıştığı gibi dürüst duygular beslediğini inandırmaya çalışır. Yukarıdaki konuşmada sosyal medyanın zararlı olduğunu, "Beni tanıyorsunuz, ben niye hiç sosyal medya kullanmıyorum" ifadesiyle kendi karakteri üzerinden anlatan Anlı, ethos yönünü öne çıkarmıştır. Diğer taraftan pathos'un en belirgin özelliği duygusal ve psikolojik öğeler öne çıkartılarak dinleyiciyle bağ kurmak ve olayların anlamlandırmasını yapmaktır. Yukarıdaki konuşmada Anlı'nın, sosyal medya kullanımına ilişkin olup bitebilecek ihtimalleri duygusal ve psikolojik canlandırmalarla inşa ettiği görülmektedir. Bunu yaparken de işinin bir parçası olmasına rağmen sosyal medyayı kullanmadığını belirterek kendi hayatından bir örnek üzerinden gitmektedir. Dolayısıyla iddia edilen konunun ispatına yönelik pathos’tan yararlandığı söylenebilir. 
Okumadınız mı? Ben diyor adam buradayım, lokantadayım, tatildeyim diyor, gidip evini soyuyorlar. Yani bunlar yaşand, bunlar yaşanırken ben tatildeyim benim çocuğum burada. İnsan çocuğunu kullanamaz. Bakın bununla ilgili yurtdışında açılmış davalar var. Mesela çok ünlü bir kadının oğlu gitti dava açtı, annem benim fotoğraflarımı kullanıyor dedi, kullanamaz dedi. Kullanamazsınız yani, bir insanın çocuğunun fotoğrafinı kullanma hakkı yok, yok. Bunlar ne kadar saçma sapan şeyler. Burada hukuksuzluk var, bakın hukukun işlediği yerlerde buralarda bile diyoruz ki hukuk işlemiyor, geç işliyor diye şikayetçi oluyoruz. Sizin o sanal alemde hukuk yok. Ben bunun üstüne yüksek lisans yaptım. Adaletin olmadığ yerde, ulaşamadığın yerde, kim olduğunu bilemediğin yerde... Çünkü yurtdışında IP numaralarla filan... Gerçekten buradakilerin, savcıların, hakimlerin de eline ayă̆ını bă̆layan uygulamalar var. Hukukun olmadığı yerde insan kendi bilgilerini böyle paylaşır mi, yapmayın. Buna bence göz önündeki insanların da topluma bu şekilde örnek olması lazım.

\section{Program 4 Şubat 2020, 50: 34}

Buradaki metin ise önceki konuşmanın devamında yer almaktadır. Anlı, aynı konuyu sürdürürken, bu sefer logos argümanlarına başvurmaktadır. Daha önce de belirtildiği gibi, dinleyicinin rasyonel etkenlerle algılama yeteneği geliştirilirken istatistik verilere ve örneklemelere yer verilebilir. Bu konuşmada “Okumadınız mı?” diyerek örnekler üzerinden gitmesi ve devamında ünlü bir kadının oğlunun annesini dava ettiğini belirtmesi, söylemlerini sağlam temellere oturttuğunu hissettirmektedir. $\mathrm{Bu}$ anlamda hukuka ve adalete göndermede bulunması, söylemin içinde oluşan kanıtlara kaynaklık etmekte ve logos'un varlığını göstermektedir. Diğer taraftan bu alandaki deneyimi doğrultusunda kendi hayatını örneklemiş ve bu konu üzerine yüksek lisans yaptığını belirterek konuşmasını desteklemiştir. Böylece dinleyiciyle duygusal bir bağ kurduğu söylenebilir. Bu durum pathos’tan da yararlandiğına işaret etmektedir.

Size bir şey söyleyeyim mi? 600 rekat namaz da insanı gerçekten her tarafinı tutturur. Hatırlarsanız bir gün ben yayına çıkamamıştım teravihinin ilk günü, iki kere akşamı kıldım (aslında yatsıyı kastetmektedir) ezan okunmadan akşamı kılmışım ben, hepsi çabuk çabuk bitsin dedim sonra ezan okunduktan sonra ben bunu niye kıldım ki dedim. Gülmeyin 13 oluyor yani iki 13, 26. Akşamı, teravihi derken şuradan çıktı̆̆ımda yürüyemiyordum yani, bütün bacaklarım tutulmuştu. Şimdi siz 600 rekat deyince yemin ediyorum her tarafim ăgrıdı yani.

\section{Program: 5 Şubat 2020, 39:34}

Müge Anlı'nın kendi deneyiminden yola çıkarak, olayı duygusal ve psikolojik yanlarıyla bağlantılandırdığg görülmektedir. Bu bağlantı kurulurken dini değerler, diğer bir deyişle inançlar öne çıkmaktadır. İnanç sisteminde ahlaki ve dini hükümler bir değeri oluşturuyorsa, genellikle ona karşı çıkmak çok zor olmaktadır (Kalender, 2000: 32). Anlatı içerisinde inanç sistemlerine bir gönderme olması, toplumun değerlerine verilen önemi de göstermektedir. 
Zira Aristo'nun belirttiği gibi, hatibin toplumun faziletleri hakkında bilgi sahibi olması, onun ethos yönünün güçlü kılmaktadır. Dolayısıyla Anlı'nın dini inancı temel alarak oluşturduğu bu argüman, hem karakterini öne çıkarttığı için ethos hem de kendi deneyimini duygusal bir bağ kurarak anlattığg için pathos merkezlidir.

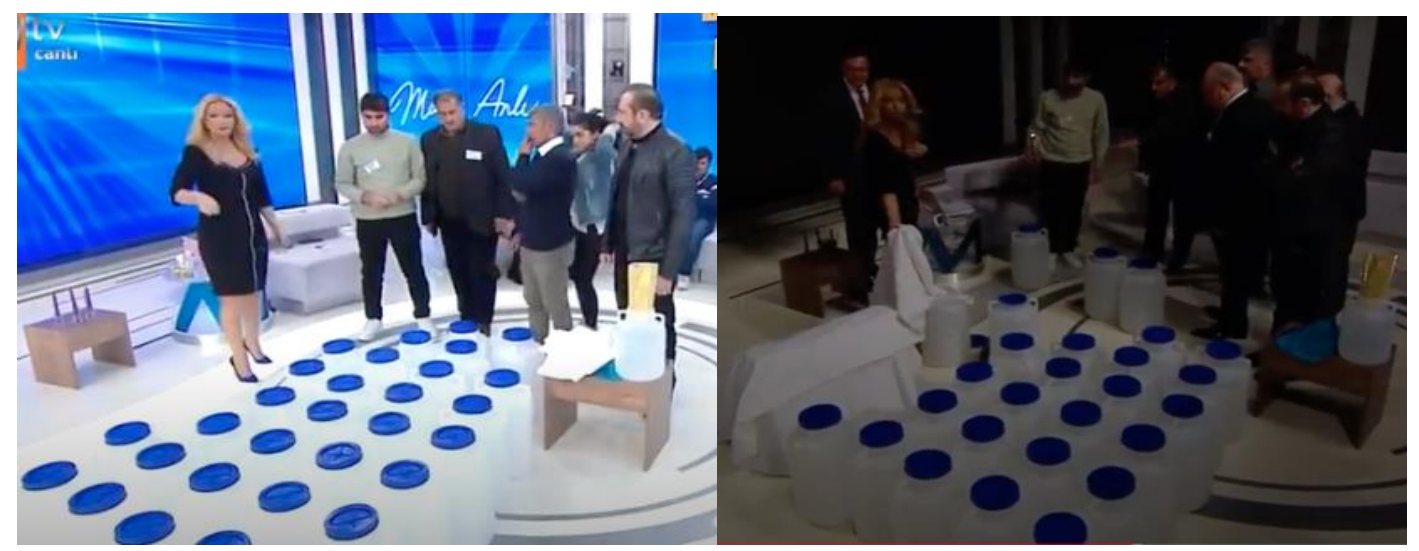

Görsel 1 (5 Şubat 2020, 1:08:00) Görsel 2 (5 Şubat 2020, 1:12:50)

Valla efendim ciddi ciddi izleyin çünkü 3 milyonu bu şekilde dolandırdılar. Hı şimdi daha iyi anladım ya altın nasıl gözüküyor diye. Bakın bu düzenek beyaz şeyle yapıldığ zaman şurasını kaldırınca siz şuradaki altını gördünüz. Siz de sanıyorsunuz ki bunun üzerinde gördüğ̈̈nüz altınlar bütün şeyin içinde var. Anladım hakikaten güzel bir sistem.

\section{Program: 5 Şubat: 2020, 1:10:18}

Yukarıdaki görselde İhsan Çapar'ın bidonlarla kurduğu düzenek stüdyoda canlandırılmıştır.

$\mathrm{Bu}$ şekilde bidonların nasıl altınlarda dolu gösterildiği izleyiciye anlatılmaya ve yaşananın bir göz yanılması olduğu kanıtlanmaya çalışılmıştır. Daha önce de belirtildiği gibi alternatif açıklamalar yapabilmek için canlı performas sergilenmesi, izleyici üzerinde olumlu etki sağlamaktadır. Hatip böyle bir canlı performans ile olayı detaylandırarak, gerçek bir olayı anlattığına dair iddiasını ispatlamış olur. Ayrıca performans sergilenirken verdiği tepkilerle bu iddiasının doğruluğunu daha da güçlendirir. Böylece logosu başarılı bir şekilde kullandığında, dinleyiciyi de aynı başarıyla ikna etmiş olacaktır. Bu anlamda Anlı'nın logos'u kullandığı görülmektedir. 


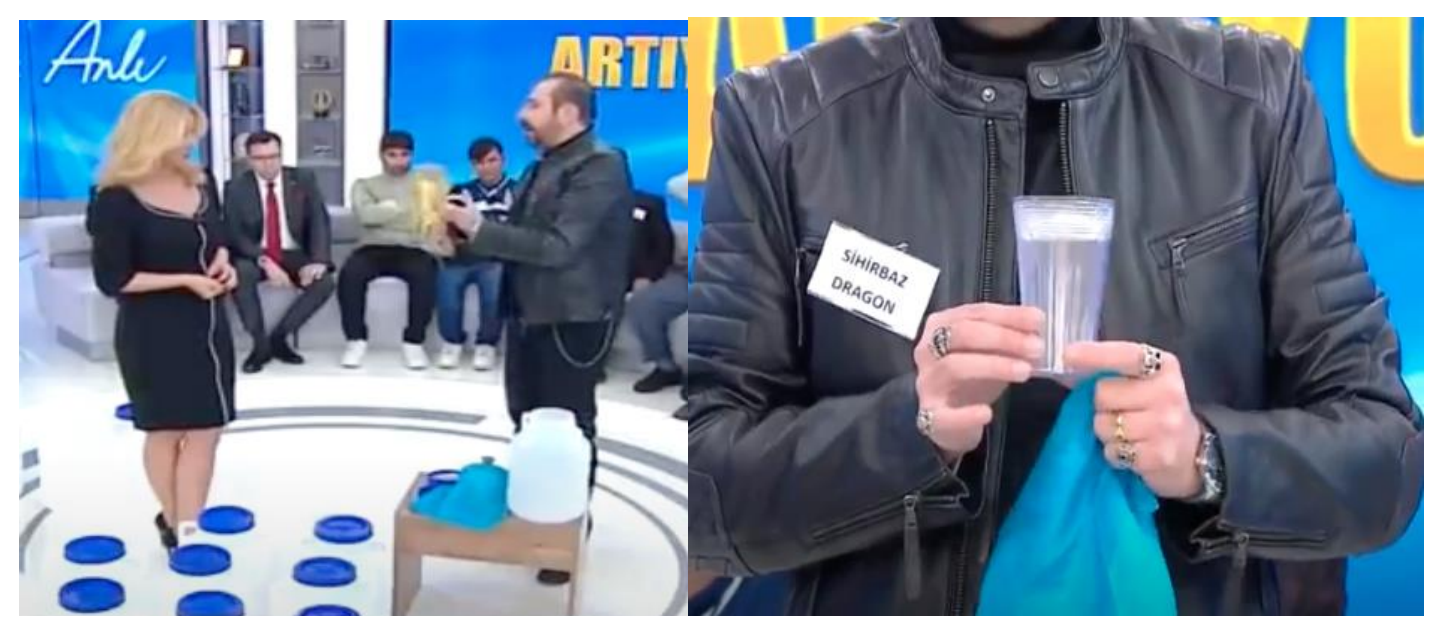

Görsel 3 (5 Şubat 2020, 1:22:43)

Görsel 4 (5 Şubat 2020, 1:24:11)

Yani arkadaşlar bunları Dragon ile beraber yapmamızın nedeni şu; bugün bu olmaz yarın başka bir şey olur. Uyanık olmamız gerekiyor.

Program: 5 Şubat 2020, 1:25:11

Bidon düzeneğiyle ilgili performansı devam ettiren Anlı, bu sefer sihirbaz Dragon isimli illüzyonistle olası ihtimalleri canlandırmaktadır. Anlı, bidonların altınlarla dolu gözükebileceği birkaç farklı oyun sergilenirken, bu tarz durumların bir yanılsama olduğunu belirterek, dinleyiciyi bu oyunlara inanmamaya ikna etmekte, bu anlamda kanıtlar üzerinden anlatısını logos ile desteklemektedir.

-Ayy çok da üzülüyorum böyle ya (...) ay canım benim ya. Ona ne kadar kaptırdın? Ay çok da iyi bir adam ha.

\section{Program: 5 Şubat 2020, 23:44-26:08}

-Benim bu kardeşlere en çok üzülmemim sebebi, paralarından da olmuşlar neredeyse canlarından da olacaklarmış. Bir de bu adamlar buraları küçük yerler İstanbul gibi değil kim kime dum duma... Adamlar çocuk kaçıran, çocuklara tecavüz eden, böbrekleri çalan adamlar olarak sosyal medyada bile lanse edilmişler.

Program: 6 Şubat 2020, 1:57:55

-Ava giderken avland falan diyorlar insanlar ama ağllyor mesela Mehmet ya ne bileyim, ben de insanlara çok üzülüyorum, gerçekten ellerindeki avuçlarındaki gitmiş.

Program: 7 Şubat 2020, 39:52

-Şimdi mikroptan dolayı sarılmıyorum örnek de olsun istiyorum. Gerçekten Adile'ye gidip sarlasim var yani

\section{Program: 4 Şubat 2020, 1:15:45}

Yukarıdaki ilk üç konuşmanın ortak noktası, ethos’un özelliği olan ve hatibin karakterini öne 
çıkaran, şefkat ve merhameti simgeleyen "üzülme" ifadesidir. Dördüncü konuşma ise yine ethos ile bağlantılı olarak alçak gönüllülükle ilgilidir. Hatibin bu tür insani özelliklere sahip olması, dinleyici tarafından iyi ve doğru davranış sergilediği izlenimi yaratır. Aristo'nun belirttiği gibi bu kişilik özelliklerine ahlaklı ve iyi insanların sahip olabileceği konusunda yaygın bir kanı vardır. Bunda hatibin konumu, giyimi, vücut dili, ses tonunun da etkisi bulunmaktadır. İyi insanlara daha kolay inanma eğilimi söz konusudur.

Ben bugüne kadar hiç Kuran'a el basmadım. "Vallahi” dediğimde bunun çok ciddi yemin olduğuna inaniyorum, o yüzden onu da çok kullanmam. Ama Kuran'a el basılıyorsa bu benim için inandırıcı bir şey, ama karşı taraf öyle değil işte. Insanların gerçekten birtakım inanışları var. Sen bu inanışların önüne geçip onları kandırırsan.... Inanıyoruz yani. Hakikaten Kuran'a el basmak önemli bir yemin benim için öyle...

\section{Program: 6 Şubat 2020, 1:32:18}

Yukarıdaki metinde Anlı'nın dini inançlar üzerinden oluşturduğu argümanlarını, kendi deneyimleriyle anlattığı görülmektedir. Bu bağlamda dinleyiciyle duygusal bir bağ kurduğu ve ethos ile pathos'u etkin bir şekilde kullandığı vurgulanabilir.

Insanlar birincisi utanıyorlar ama asıl önemlisi korkuyorlar hala daha. Kuran'a el basmışlar ya insanlar, hani bu durumu anlatmayacağız kimseye diye. Polise, sacıya, jandarmaya gidip bu yaşananı bu şekilde anlatamıyorlar. Ama şimdi artık sizler çıktınız ve herkesin de bu konudaki korkularını bertaraf ettiniz. Hala korkan varsa rica ediyorum, bunda korkulacak bir şey yok yapmayın ne olur. Bizden önce sayın Nihat Hatipoğlu da bu konuya dikkat çekti uzun uzun anlattı, konuştu. "Aklın kabul etmediğini din kabul eder mi" diyor. "Ortada cin falan yok cin fikir var" diyor, çok hoşuma gitti. Gerçekten bu cin fikir, insanları mağdur etmiş.

\section{Program: 7 Şubat 2020, 20:54}

Anlı'nın dini inançlarla ilgili daha önce oluşturduğu argümanlarını desteklemek amacıyla, bir din profesörüne atıfta bulunduğu görülmektedir. Ayrıca Nihat Hatipoğlu'nun konuşmasına da programda yer vermiştir. Güzel'in (2016: 56-57) ethos'la ilgili ifadelerinde de belirtildiği gibi hatip, kendi bakış açısını alternatif açıklamalarla pekiştiren bir kaynağa başvurabilir. Böylelikle dinleyicide oluşabilecek olumsuz düşünceleri ön görerek, bu yargıları ortadan kaldıracak girişimde bulunur. Müge Anlı'ın tanınan bir din profesörüne başvurması sonucunda hem ethos hem de kanıtlama girişiminde bulunduğu için logos temel alınmaktadır. Zaten Çodur'un (2017: 68) da ifade ettiği gibi ethos ve logos birbirine sıkı bir şekilde bağlıdır.

Hani biz dedik ya Ingiliz parası, hani eski bir para falan. Bunlar 1920'de Suriye'de basılan Ingiliz paralarının sahtesini yapıp Suriye'den buraya getiriyorlarmış. Neden? Işste kalpazanlık olmasın. Şimdi normal ata lira, ziynet falan verilirse, bu tabi burada kalpazanlı̆̆a giriyor. Onun suçu ayrıca ekstra olacak. Her şey aslında o kadar güzel planlanmış ki. 


\section{Program: 7 Şubat 2020, 14:50}

İddialara göre İhsan Çapar ve hoca lakaplı kişi, Suriyeli bir mülteciyle işbirliği içerisinde insanları dolandırmaktadır. Odada çuvallardan çıkan altın benzeri maddenin örnekleri, dolandırılan mağdurlarda bulunmaktadır. Canlı yayında bu sahte paraları inceleyen Anlı, yayın sonrası bu paralarla ilgili yapılan araştırmanın sonucunu açıklamaktadır. Daha önce de belirtildiği gibi örneklemeler, istatistikler, vaka analizleri vb. dinleyicinin rasyonel etkenlerle algılama yeteneğini geliştirmektedir. Burada sahte paralarla ilgili vaka analizi yapılması ve bunun dinleyiciye açıklanması, konuşmanın logos yönünü öne çıkarmaktadır. $\mathrm{Bu}$ anlamda hatibin "paraları Suriye'den getirme nedenini kalpazanlığa girmemesi için” şeklindeki açıklaması, mantığa dayalı akıl yürüttüğünü göstermektedir. Dolayısıyla hatip, söylediklerini tutarlı bir şekilde kurgulamıştır.

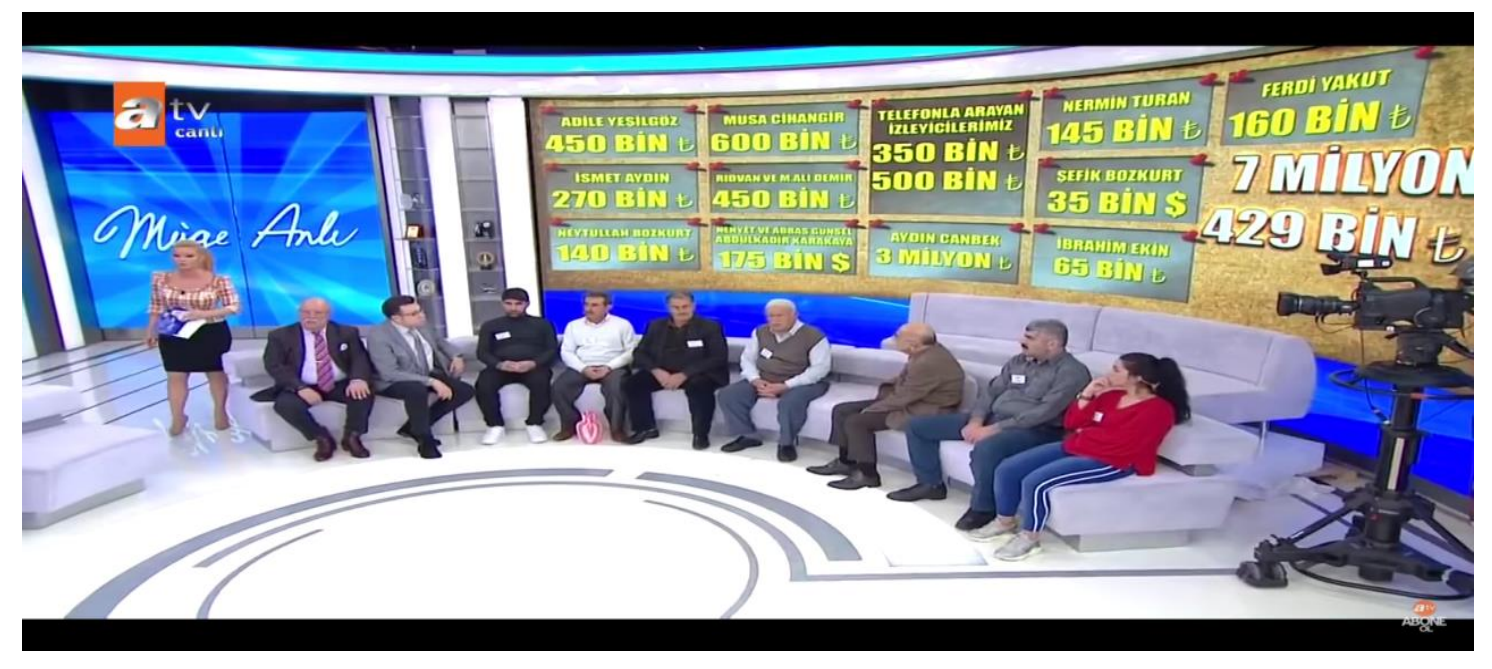

\section{Görsel: 5 (6 Şubat 2020, 1:11:30)}

Görsel 5'te olayın işlendiği süreç boyunca, telefonlardan gelen dolandırılma ihbarları da dahil, Türkiye genelinde toplam para miktarı istatistik verilerle tablolaştırılmıştır. Buna göre yaklaşık 7.5 milyonluk vurgunun anlatılmasında, logos'un özelliği olan istatistik verilerle kanıtlama yoluna gidilmiştir. Böylece olayın büyüklüğü gözler önüne serilmektedir.

Ihan Çapar, nitelikli dolandırıcıllk suçunda tutuklanarak ceza evine gönderildi. Ben bu bütün teşekkürleri ve çiçekleri başta Mardin valisi Mustafa Yaman, Mardin Il Emniyet Müdürü Hakan Çetinkaya, Şanlıurfa İl Emniyet Müdürü, Mardin Asayiş Şube Müdürü Ayhan Söğ̈̈t, Mardin Yan Kesicilik ve Dolandırıcılık Büro Amirliği ve tüm personeline, Mardin Savur Cumhuriyet Savcımıza, Şanlıurfa Emniyet Müdürlügü Kaçakçılık ve Organize Suçlarla Mücadele Şube Müdürlüğ̈̈ adına falan alıyorum. Aslında o kadar çok söylemek istediğim kişiler var ki, çok teşekkür ediyorum her birine. Jandarmamıza teşekkür ediyorum, emniyet müdürlüğ̈̈müze teşekkür ediyorum. Mardin ve Şanlıurfa'daki tüm personele teşekkür ediyorum. Mardin Savur savcısı asıl teşekkürüm kendisine. Ben çok mutluyum gerçekten devlet de kararlığını gösterdiği 
için, zaten her zaman devletimle gurur duyuyorum. Bu kararlılıktan dolayı da teşekkür ediyorum devletin tüm mensuplarına tüm çalışanlarına. Olması gerek buydu. Daha burada sizin şikayetleriniz yok. Bu savur savcılığının titiz bir şekilde takip etmesiyle yapılan bir tutuklama. Gerçekten savur savcısının büyükse ellerinden küçükse gözlerinden öpüyorum, onun slkı takibi olayın üzerinde dirayetli bir şekilde duruşuyla ortaya çıkan bir sonuç.

\section{Program: 10 Şubat 2020, 5:18}

Yukarıdaki metin oldukça coşkuyla kutlanan bir hava içerisinde yapılan bir konuşmadır. Devletin resmi kurumları övülmektedir. Diğer taraftan dinleyicide şiddetli duygular ve çeşitli teessürler uyandırılmıştır. Bu bağlamda konuşmada pathos'tan yararlanıldığı ve retoriğin epideiktik/törensel türüne girdiği söylenebilir. Bu söylevde hatibin devlete olan saygısı ve ona olan inancı öne çıkmaktadır. Ethos başlığında da anlattığımız gibi saygı, iyi bir insan olarak değerlendirilebilecek hatipte olması gereken bir özelliktir.

Son olarak ise hatibin sürekli devlet kurumlarına atıf yapması adli/hukuki söylevde bulunduğunu göstermektedir. Suçlu olduğu düşünülen insanların suçlarını ortaya çıkarma konusunda hukuki retorikten yararlanılmaktadır, bu anlamda bu konuşma logos'un özelliklerini de taşımaktadır. Sonuç olarak bu söylevde ethos-pathos-logos yoğun bir şekilde görülmektedir.

Tüm bu bulgular neticesinde, yukarıda Müge Anlı'nın hangi cümlelerinden hangi verilerin çıkarıldığı, hangi kavramlarla ve görsellerdeki unsunrlarla ethos, pathos, logos'un ilişkilendirildiği ortaya konmuş, aşağıdaki tabloda ise hangi ikna bileşenlerini kullanarak argümanlarını geliştirdiği özetlenmiştir.

Tablo 2: Müge Anlı’nın İknanın Üç Kanıtında Öne Çıkan ve Tespit Edilen Yönleri

Karakter özellikleri: Sezgili, vicdanlı, sorumluluk alan, şefkatli ve merhametli, candan ve alçak gönüllü, doğru ve dürüst, güvenilir ve saygılı olan, inancı temel alarak dini değerleri ve toplumun faziletlerini önemseyen, olağanüstü olaylara inanmayan, kendi düşüncelerini alternatif açıklamalarla pekiştiren kişilik

Ethos yapısındadir.

Beden Dili: Giyim, sesin alçaltıp yükseltilmesi, ses tonu, sesin ciddiyeti, yüz ifadesi, el kol hareketlerinin aktif kullanımı önemlidir.

Sosyal Statü: Eğitim, mesleki konum, sosyoekonomik durum, güçlü çıkarım yapabilen zeka sahibidir. 
Pathos Kendi hayatından örnekler vererek seyirciyle duygusal bir bağ kurar ve onlarda çeşitli coşku uyandırıcı argümanlar kullanır.

Öne sürdüğü argümanları kanıtlara dayandırır. Bunun için hukuka (yasalara ve Logos kanunlara), somut belgelere, örneklemelere, istatistik verilere, canlı performanslara, canlandırmalara, vaka analizlerine başvurmakta ve böylece konuşmasını mantıki temeller üzerine inşa etmektedir.

\section{SONUÇ}

Antik çağlardan günümüze kadar gelen retorik, etkili konuşma sanatı olarak görülmüş ve birçok kavramı da içine alacak şekilde gelişmiştir. Bu anlamda gelişen kavramlardan ethos, pathos ve logos, retoriğin temel unsurlarını oluşturmakta ve ikna edici konuşmanın kanıtları olarak nitelendirilmektedir. $\mathrm{Bu}$ üç kavramın özelliklerini bünyesinde barındıran hatibin, muhatabını ikna etmede üstün bir yeteneğe sahip olduğu söylenebilir. Oluşturduğu argümanlarla, takındığı tavır ve davranışlarla etkili ve ikna edici konuşma sanatını icra edebilme yeteneğine sahip olan hatip, pek çok kapıyı ardına kadar açabilir. Bu noktada hatibin ethos, pathos, logos'u nasıl kullandığı oldukça önem arz etmektedir.

Türkiye'de birçok olay aydınlanmayarak tarafların yıllarca ızdırap çekmesine ve toplumsal korkulara yol açabilmektedir. Bu olaylar arasında kadın-erkek cinayetleri, kayıp arama, kaçırılma, çocuk istismarı, evlilik vaadiyle dolandırılma gibi konuları saymak mümkündür. Bu bağlamda medyada özellikle de televizyonda programcıların/sunucuların bu konulara taraf olanları konuk olmaya ikna etmesi, olayların gerçek yüzünü itiraf etmelerini sağlaması, yıllarca gizli kalmış olayları gün yüzüne çıkararak açıklığa kavuşturması vb. onların verdikleri güven ve inandırıcılıkla doğrudan bağlantılıdır. Bu programcı ya da sunuculardan biri olan Müge Anlı 2008 yılından bu güne geçmişte yaşanmış olayların taraflarını ikna ederek ekrana çıkarmakta, kişileri başarıyla konuşturmakta ve sonuçta olayları aydınlatmaktadır. İşte bu başarıyı sağlama noktasında Anlı'nın kullandığı retoriksel unsurları nasıl kurguladığını tespit etmek, çalışmanın amacını oluşturmaktadır. Bu çalışmanın benzer program yapanlar için Müge Anlı'nın başarısını daha kolay anlayabilmesine ve kendi programlarında yararlanmalarına katkı sunması umulmaktadır.

"Kurgu olmayan reality show" olarak ifade edilen Müge Anlı ile Tatll Sert programı haftaiçi her gün canlı olarak 4 saate yakın bir süre boyunca kadın-erkek cinayetleri, kayıp arama, kaçırılma, çocuk istismarı, evlilik vaadiyle dolandırılma gibi konulara parmak basmaktadır. Bugüne kadar birçok olayı çözüme ulaştırmış olan program, toplumda yaşanan gerçek olayları 
yine topluma aktarmaktadır. Bu aktarılma esnasında ise Müge Anlı'nın konuları işleyiş biçimi aynı zamanda kendi yaklaşımlarını da açığa çıkarmaktadır. Kendi tutumları, inançları, psikolojik yapısı, bilgisi, mesleki tecrübesi, eğitimi, sosyoekonomik durumu, sosyal statüsü kısaca kişilik özellikleri ve karakteri de olayları yorumlamasında büyük bir etkendir. Diğer taraftan yine konuyu işleyişi sırasında, programa katılan konukların yaşadıklarına kayıtsız kalamaması; söz gelimi üzülmesi, sevinmesi, saygılı olması, alçak gönüllü davranması, adil olması gibi unsurlar onun kişiliğinin önemli bir parçasını oluşturmakta, bu anlamda "iyi insan" nitelemesine uygun bulunmaktadır. Ayrıca Anlı, program kapsamında sevgi izi, patibuldular, aşevi, engelliler için akülü sandalye, Doğu'da kitabı olmayan okullar için kitap sağlama gibi pek çok sosyal sorumluluk projesine imza atmaktadır. Tüm bu özellikler "adetler ve faziletler hakkında bilgisi” olan ve ahlaki temellere dayanan "güvenilir bir kişiı" portresi çizmektedir. Bu bağlamda da ethos yönü güçlü olan bir hatibe gönderme yaparak, ikna sanatının ilk ayağını oluşturmaktadır.

Kanunlar, yasalar, genel-geçer doğrular, istatistik veriler, örneklemeler, vaka analizleri, canlı performanslar, alanında tecrübeli uzmanların görüşlerine başvurma gibi pek çok unsur, mantıki temeller üzerinden kurgulanarak Müge Anlı'nın söylemlerinde kanıt olarak sunulmaktadır. Bu anlamda Anlı, hedef kitlesinin rasyonel etkenlerle algılama gücünü, sağlam temellere dayandırmaktadır. Bu şekilde akılda soru işareti kalması engellenmekte, olaylarla ilgili detaylar verilerek anlatılan konuya dair argümanlar geliştirilmektedir. Böylelikle Anlı'nın akı1 yürüterek oluşturduğu argümanları, tutarlı bir yapıda kurguladığı görülmektedir. Bunun yanı sıra ikna konusunda etkileyici unsurlar olarak görülen ve Anlı'da da şekil bulan el, kol, yüz hareketleri, sesin alçaltılıp yükseltilmesi, sergilenen tavır ve davranış ana düşünceyi desteklemektedir. Tüm bu etmenler, Anlı'nın logos yönünü öne çıkarmakta, bu anlamda “argümantasyon yapabilecek durumda olduğunu” görmemizi sağlamaktadır. Dolayısıyla mantığa dayalı akıl yürütme durumuna başvurma, ikna sanatının ikinci ayağını oluşturur.

Müge Anlı olayları yorumlarken sıklıkla duygusal ve psikolojik bağlamlarla değerlendirmelerde bulunur. Söylemlerinin içindeki duygusal öğe, değerler ve inançlarla da doğrudan bağlantılıdır. Anlı bu bağlantıları kendi hayatından örnekler vererek kurmaktadır. Böylece hedef kitlenin empati kurmasını sağlamak ve aynı duyguları paylaştığını anlatmak kolaylaşmaktadır. İnsan psikolojisinin duygusal öğelerden daha kolay etkilendiği düşünüldüğünde, hatibin bu tarz bir yaklaşım sergilemesi, dinleyicinin ruhunu iyi analiz edebildiğini gösterir. Diğer taraftan hatip ve muhatap arasında fikir ayrılığı da söz konusu olabilir. Bu noktada hatibin duygusal bağlantılarla olayı anlamlandırması, dinleyicinin 
düşüncelerinde bir değişim meydana getirebilir. Söz gelimi Anlı'nın sosyal medyanın zararlarına yönelik oluşturduğu argümanda, kendinden yola çıkarak iddialarını kanıtlamaya çalışması bir dönüşüm gerçekleştirebilir. Bu durum anlatılanlarının doğru kabul görmesine dayanır. Dolayısıyla Anlı sadece aklı değil duyguları da temel alarak argümanlarını geliştirir. Böylece "muhatabında çeşitli teessürler ya da şiddetli duygular uyandırmanın yollarını bilen" Anlı, pathos'un gücünden yararlanmaktadır. Pathos'u kullanarak dinleyicinin coşkularına hitap etmek, ikna edici konuşma sanatının üçüncü ayağını oluşturur.

Başarılı bir retorik, iknanın üç kanıtı olarak belirtilen ethos, pathos ve logos birlikteliğinden doğmaktadır. $\mathrm{Bu}$ anlamda bir hatip olarak nitelendirebileceğimiz Müge Anlı’nın işlediği konuda bu üç unsuru etkin bir şekilde kullandığı tespit edilmiş, muhataplarını ikna edecek argümanları oluşturduğu sonucuna varılmıştır. Bu bağlamda Müge Anlı, yıllardır aynı programı sürdürmeyi beceren başarılı bir retorik sunucusudur. Anlı'nın bu sanatı kullanmasının sebebi; heyecan yaratıcı ve sürükleyici şekilde bir dedektif gibi konuları işleyerek izlenirliğini artırmak, bu anlamda reyting kazanmak, neticeye kazandırdığı olaylar sebebiyle programa katılımcı çekmek ve örnek olaylar üzerinden toplumu bilinçlendirmek şeklinde yorumlanabilir. Bu konuyu bundan sonra yapılacak bir saha çalışmasıyla seyirci nezdinde alımlama analizi çerçevesinden geliştirmek ve incelemek, konuyla ilgili literatürü zenginleştirmek adına olumlu olabilir.

\section{KAYNAKÇA}

Altınörs, Atakan (2011). Platon ile Aristoteles'in Retorik Anlayışlarının Karşılaştırılması. Ekec Akademi Dergisi, sayı: 49, s.81-92.

Aristoteles. (1995). Retorik. Mehmet H. Doğan (çev). İstanbul: YKY.

Başarır, Murat (2016). Retorik İkna Bileşenlerin Siyasi Liderlerce Kullanımı: İktidar ve Ana Muhalefet Liderlerinin TBMM Grup Konuşmaları Üzerine Bir Analiz. Gümüşhane Üniversitesi İletişim Fakültesi Elektronik Dergisi, 2(4), s.703-724.

Bıçakçı, Ayşe Banu (2012). İkna Edici İletişim ve Retorik Analiz. İletişim Bilimleri Araştırma Yöntemleri Yazılı Metin Çözümleme içinde. (334-362). (Editör), Özlem Güllüoğlu. Ankara: Ütopya.

Byers, Breanna Lee (2009). Enacting ethos online: Using classical rhetoric to analyze visual Web design, Tamamlanmamış Yüksek Lisans Tezi, Iowa State University, Ames, Iowa. Creswell, John W. (2007). Qualitative Inquiry Research Design (2. Bask1). London: Sage. 
Çam, Mehmet Safa (2015). Türkiye'de Basın Reklamlarının Retoriği: Otohaber Dergisinde 1992 ve 2012 Yıllarında Yayınlanan Otomobil İlanlarının Karşılaştırmalı Analizi, Yüksek Lisans Tezi, Ankara Üniversitesi Sos. Bil. Enst., Ankara.

Çodur, Gökben (2017). Siyasal Reklamcılık Retoriği: 2014 Cumhurbaşkanlığı Seçimlerinde Sosyal Medyada Yayınlanan Reklamların İçerik Analizi. Maltepe Üniversitesi Sos. Bil. Enst., İstanbul.

Gerring, John (2007). Case Study Research Principles and Practices. New York: Cambridge University Press.

Güzel, Cavit (2016). Kırşehir'den Derlenen Efsanelerin Retorik Analizi, Doktora Tezi, Kırşehir Ahi Evran Üniversitesi Sos. Bil. Enst., Kırşehir.

Hancock, Dawson R., ve Algozzine, Bob (2006). Doing Case Study Research. New York: Teachers College Press.

Kalender, Ahmet (2000). Siyasal İletişim: Seçmenler ve İkna Stratejileri. Konya: Çizgi.

Karaman, Sıla (2012). Retorikte Genel İnandırma Tarzları Hakkında Bir İnceleme, Yüksek Lisans Tezi, DEU Sos. Bil. Enst., İzmir.

Karaman, Seyhan (2019). Türkiye’de Haberciliğin Dönüşümü ve Retorik, Yüksek Lisans Tezi, ÜÜ Sos. Bil. Enst., İstanbul.

Koçak, "Şeyda "Aristoteles ve Retorik".

http://www.academia.edu/5808466/Aristoteles_ve_Retorik Erişim Tarihi: 02.04.2020.

Köklüdağ, Mehmet (2016). Retorik Kitap Tanıtım ve Değerlendirlemeler. Ondokuz Mayıs Üniversitesi İlahiyet Fakültesi Dergisi, 40 s.202-206.

Küçükcan, Özlem Uluç (2019). Medya Sarkacı: Kurgu ile Gerçeklik Arasında Suç. Türk Dünya Araştırmaları Vakfı (TDA), 242(123), s.11-34.

Meyer, Michel (2004). Retorik. İsmail Yerguz (çev.). Ankara: Dost Kitabevi Yayınları.

Mediacat, $2019 \quad$ https://mediacat.com/turkiyenin-en-guvenilir-unluleri-karsinizda/ Erişim Tarihi: 20.03.2020.

McCormack, Krista C. (2014). Ethos, Pathos, and Logos: The Benefits of Aristotelian Rhetoric in the Courtroom. 7 Wash. U. Jur. Rev. 131.

Miles, Matthew B. ve Huberman, A. Michael (1994). Qualitative Data Analysis.(2. Bask1). London: Sage. 
Nas, Alparslan (2013). Reklam Bağlamında İkna ve Retorik. İletişim Ve... içinde (11-42). Ruken Özgül Kılanç (der.). İstanbul: Es Yayınları.

Stake, Robert E. (2003). Case Studies. https://www.sfu.ca/ palys/Stake2003-CaseStudies.pdf Subaşı, Münevver ve Okumuş, Kübra (2017). Bir Araştırma Yöntemi Olarak Durum Çalışması. Atatürk Üniversitesi Sosyal Bilimler Dergisi, 21(2), s. 419-426.

Tabak, Dilara Karakaş (2015). Güncel Sanatin Manipülasyon Yönelimlerine Katkısında Görsel Retorik, Doktora Tezi, OMÜ Eğitim Bil. Enst., Samsun.

Temir, Erkam (2019). Siyasal İletişimde Retorik: Aleksey Navalnıy Örneği, Doktora Tezi, ERÜ Sos. Bil. Enst., Kayseri.

Yin, Robert K. (1984). Case Study Research Design and Methods. (2. Bask1). London: Sage.

Zafer, Senem Bayartan (2017a). 2000 Y11 Sonrasında Dergilerde Yayınlanan Axe Reklamların Görsel Retorik ve Figüratif Dil Kullanımının Karşılaştırmalı İçerik Analizi, Yüksek Lisans Tezi, İstanbul Ticaret Üniversitesi Sos. Bil. Enst., İstanbul.

Zafer, Senem (2017b). Üç İkna Kanıtı ve Reklamlarda Kullanımı. (Tartışma Metinleri) İstanbul Ticaret Üniversitesi Dış Ticaret Enst., İstanbul

Zeybek, Burcu (2015). Türkiye’de Gazetelerin Yayınlandığı Siyasal Reklamlarda Retorik Türlerin Kullanımı, Doktora Tezi, İÜ Sos. Bil. Enst., İstanbul. 